\title{
Morphological Characterization and Genetic Diversity of Fusarium spp. Infecting Bitter Gourd
}

\author{
M. Saran Kumar ${ }^{1 *}$, S. K. Manoranjitham ${ }^{1}$, V. Sendhilvel ${ }^{1}$ and V. Rajasree $^{2}$ \\ ${ }^{1}$ Department of Plant Pathology, Tamil Nadu Agricultural University, \\ Coimbatore - 641 003, India \\ ${ }^{2}$ Department of Vegetable Science, Tamil Nadu Agricultural University, \\ Coimbatore - 641 003, India \\ *Corresponding author
}

\section{A B S T R A C T}

\begin{tabular}{|c|}
\hline Keywords \\
\hline $\begin{array}{l}\text { Bitter gourd, } \\
\text { Fusarium spp., } \\
\text { Pathogenicity, PCR } \\
\text { amplification, } \\
\text { Genetic diversity. }\end{array}$ \\
\hline Article Info \\
\hline $\begin{array}{l}\text { Accepted: } \\
05 \text { April } 2020 \\
\text { Available Online: } \\
10 \text { May } 2020\end{array}$ \\
\hline
\end{tabular}

Bitter gourd (Momordica charantiaL.) is an important cucurbitaceous plant in which the deleterious diseases namely vascular wilt, damping off occurs commonly and causes 30 to 50 percent losses in crop. The present investigation was aimed to study the morphological and molecular characterization of disease causing pathogen to understand the etiology of the disease. Survey was conducted at different locations of Coimbatore, Erode and Dharmapuri and samples were collected for the isolation of the pathogen. The pathogen was isolated from the brownish discoloured vascular tissue of stem portion which was typically wilted. Pathogenicity assay was proved and the virulence of the fusarium isolates were identified under artificial inoculation studies. The morphological studies of Fusarium isolates were studied using the microscopic observation to study the micro and macro conidial variation .The molecular confirmation of pathogen was done by PCR amplification using ITS 1 and ITS 4primer at $560 \mathrm{bp}$. The different species of Fusarium solani, Fusarium equiseti, Fusarium falciforme, Fusarium chlamydosporum and Fusarium incarnatumwere identified in these molecular studies. Among the species, Fusarium solani is a major pathogen associated with bitter gourd wilt disease. The genetic variability studies among different Fusariumspp. was carried out using RAPD marker. The variability studies revealed that virulence isolates viz, F. solani VP, F. solani EL, $F$. solani TP, $F$. falciforme $\mathrm{IJ}$ and $F$. chlamydosporum $\mathrm{TN}$ were grouped into cluster II which are more virulent and the same results were shown in pathogenicity. The wilt pathogen of bitter gourd isolated from the palee hybrid was shown more virulence when compared to the other isolates.

\section{Introduction}

Bitter gourd (Momordica charantia L.) is one of the important cucurbitaceous vegetable grown in India. Among the cucurbits, it is prized vegetable which is having high nutritive value especially ascorbic acid and iron (Behera2004). For culinary preparations immature fruits and tender vine tips are used. It is a most common vegetable cultivated throughout India during warm season (Satkar et al., 2013). Bitter gourd has been used in various herbal medicine systems. Phytochemical compounds like dietary fiber, minerals, vitamins, flavonoids and antioxidants involved in health promoting and 
disease prevention. It is also used for reduction of blood sugar levels in the treatment of type-2 diabete (Singh et al., 2013). The crop is cultivated with an area of 99,000 ha in India with an annual production of $11,98,000 \mathrm{MT}$ and the productivity of 12.18MT/ha (Indiastat 2018-19). Wilt disease caused by Fusarium spp. the main constraint with bitter gourd cultivation in India. (Tamilselvi2014). It is the most devastating soil borne disease and one of the major yields limiting constraint which cause profound economic losses ranging from 30 to 50 per cent under dry warm conditions (Tamilselvi and Pugalendhi 2015). The knowledge on host pathogen interaction and predominating of causative agents are not explained. Hence considering this idea in mind, the present investigation was carried out to study the morphological and molecular variability of the pathogen and to the etiology of the disease.

\section{Materials and Methods}

\section{Survey and collection of plant materials}

The survey was conducted in around Coimbatore, Erode and Dharmapuri districts of Tamil Nadu. Thediseased plants showing typical disease symptom were collected from ten different fields. Thetotal numbers of plants wilted were recorded in sq. meter of area and the Percent Disease Incidence (PDI) was calculated for each field location as methodology explained by Muhammad et al., (2019).

\section{Symptomatology}

A symptom of fusarium wilt includes damping-off, seedling disease or wilt during any stage of plant development. Symptoms on mature plants typically appear as a dull grey green appearance of the leaves followed by yellowing of the crown foliage, wilting during the day and eventual death. Brown stripes will develop on stems and branches of infected plants (Tamilselvi et al., 2016). Vascular discoloration is visible inside the stem and stem collarturn dark brown (Fig.1).

\section{Isolation and purification of pathogen}

The wilt infected vascular tissue was taken from the infected parts of the plant, sterilized in a $0.5 \%$ sodium hypochlorite solution, rinsed with sterilized water for three times and placed on Potato Dextrose Agar (PDA) medium. The medium was supplemented with $0.5 \mathrm{gL}^{-1}$ of streptomycin sulphate to avoid the bacterial contamination. After that the Petri dishes were incubated at $25 \pm 1^{\circ} \mathrm{C}$ for 7 days (Muhammad et al., 2019). The colony produced from diseased sample were reisolated using a single spore where the fungal colonies emerged from diseased samples were transferred to different Petri dishes containing fresh PDA medium for pure culture.

\section{Pathogenicity}

In order to confirm the pathogenic nature of isolated fungal pathogen, the pathogenicity test was conducted in earthen pots.

\section{Inoculum preparation and inoculation}

Sand maize medium was used for mass multiplication of the fungal isolate in the laboratory. The medium was prepared with ratio of 19:1 sterilized in an autoclave at 15 lbs psi for 30 minutes. Sand maize medium was inoculated with pure culture of Fusarium isolates in aseptic conditions and incubated in an incubator at $28+2^{0} \mathrm{C}$ for 15 days (Ashwathi et al., 2017).

\section{Preparation of planting material}

Bitter gourd seeds CO1 were sown in the earthen pots containing sterilized potting soil. 
Sand maize medium was prepared and mixed with proportion of $100 \mathrm{mg}$ inoculum $/ \mathrm{kg}$ of potting mixture and sowing was taken.

\section{Morphological and microscopic identification of pathogen}

The fungal pure culture was transferred to new Potato Dextrose Agar (PDA) to facilitate for the growth of mycelia and sporulation of conidia for the identification of pathogen through Labomed camera model LX400 microscope with image analyser pixel pro program at 40x magnification using sterile water (Karthick et al., 2019). The pathogens were identified based on the microscopic analysis, microconidia and macroconidia characteristics such as colour, shape and size, and also the presence chlamydospore were studied and tabulated.

\section{Molecular identification of the isolated fungi}

The pure fungal isolates were taken for the DNA isolation using CTAB method described by Chowdhury et al., (2019). The isolated DNA were amplified through polymerase Chain Reaction (PCR) technique using universal primers, ITS1 (5'-TCC GTA GCT GAA CCT GCC G-3') and ITS4 (5'-TCC TCC GCT TAT TGA TAT GC-3') developed by White et al., (1990) and Hot Start Green Master Mix (Promega, USA). PCR was performed in a $50 \mu$ l reaction mixture containing $25 \mu \mathrm{l}$ of Hot Start Green Master Mix (2X), 2.0 $\mu$ l of each forward and reverse primer, 2.0 $\mu$ l of genomic DNA and rest of the PCR water. The performing PCR program was as follows: pre heat at $95^{\circ} \mathrm{C}$ for $2 \mathrm{~min}$, followed by 40 cycles of denaturation step at $95^{\circ} \mathrm{C}$ for $1 \mathrm{~min}$, primer annealing at $58^{\circ} \mathrm{C}$ for $1 \mathrm{~min}$, primer extension at $72^{\circ} \mathrm{C}$ for $1 \mathrm{~min}$ with a final extension at $72^{\circ} \mathrm{C}$ for $5 \mathrm{~min}$, hold at $10^{\circ} \mathrm{C}$ for overnight. The amplicons were separated by $1 \%$ agarose (V3125, Promega,
USA) gel electrophoresis (Karthick et al., 2019a). The quality and quantity of isolated DNA were checked by NanoDrop Spectrophotometer (ND2000, Thermo Scientific, USA). Finally, The PCR products were purified and used for sequencing analysis in Barcode Bioscience Pvt ltd, Bangalore(India). The sequenced data were analysed using similarities of nucleotide sequences between isolates through the BLAST procedure (http://blast.ncbi.nlm.nih.gov).

\section{Molecular variability studies}

\section{RAPD-PCR analysis of fusarium spp.}

Genotypic characterization of the Fusarium spp. isolateswas done by using a PCR-based fingerprinting of randomly amplified polymorphic DNA (RAPD) markers method described by Bentley et al., (1995). PCR amplification was performed using an Eppendorf nexus gradient master cycler and a $20 \mu 1$ total volume containing 2.0 units of Taq polymerase (Bangalore Genei Pvt Ltd, India), $2 \mu \mathrm{l}$ of $10 \mathrm{X}$ buffer, $1.5 \mu \mathrm{l}$ of $2.5 \mathrm{mM} \mathrm{MgCl}_{2}$, $1 \mu \mathrm{l}$ of $2.5 \mathrm{mM}$ dNTP, $2 \mu \mathrm{l}$ of $10 \mu \mathrm{M}$ primer, $4 \mu \mathrm{l}$ of genomic DNA and sterile distilled water. The PCR was performed, using Eppendorf - Master Cycler nexus gradient S (Eppendorf, A G, Hamburg, Germany), with an initial denaturation step for $5 \mathrm{~min}$ at $94^{\circ} \mathrm{C}$, followed by 35 cycles of $1 \mathrm{~min}$ for denaturation at $94^{\circ} \mathrm{C}, 1 \mathrm{~min}$ for annealing at $36^{\circ} \mathrm{C}$ and $1 \mathrm{~min}$ for extension at $72^{\circ} \mathrm{C}$, with a final extension for $5 \mathrm{~min}$ at $72^{\circ} \mathrm{C}$. Following amplification, $20 \mu \mathrm{l}$ of each PCR product was separated by electrophoresis in $1.0 \%(\mathrm{w} / \mathrm{v})$ agarose gel in Tris-acetate-EDTA (TAE) buffer.To visualize amplified DNA, fragments gels were stained with an ethidium bromide $\left(0.1 \mathrm{mg}^{-1}\right)$ and then photographed under transmission ultraviolet light, using an Alpha Imager 2000 (Alpha Innotech, San Leandro, CA, USA). 
The whole RAPD analyses experiment was repeated at least three times for all primers and isolates and only the RAPD bands which appeared consistently were evaluated for polymorphism. Using the software DARwin 6 , the dendrogram constructed. The RAPD primers are given below table.1.

\section{Results and Discussion}

\section{Isolation and purification of pathogen}

In this study, the different fusarium wilt disease infected fields were surveyed which showing typical symptoms. The wilt pathogens were isolated and listed in the Table.2. The results revealed that the disease incidence was maximum at Madhampatti (59.3\%) followed by Papampatti (55.4\%) villages of Coimbatore district. The least disease incidence $(15.6 \%)$ was observed at TNAU vegetable garden followed by the Injampalayam (20.3\%) Erode district.

\section{Pathogenicity test}

The assay on pathogenicity, plants were shown different period of wilting incidence after the inoculation of pathogen. After inoculation of pathogen, plants initially had shown yellowing of foliage, pale green appearance of leaves, day wilting followed by death. Inside the stem, vascular browning of tissues was found (Fig.2).

The present findings were similar with the Ashwathi et al., (2017) studies that the fusarium wilt of coriander symptom expression was observed under the sand maize inoculation of pathogen which shown reddish brown lesions at collar portion, gridling and toppling down of seedlings on $15^{\text {th }}$ day. The Koch's postulates were proved. This study revealed that the isolate Fusarium solani was more virulent followed by Fusarium equiseti(Table.3).

\section{Morphological and molecular identification of pathogen}

In morphological identification of pathogen, Fusarium solani, macro conidia have slightly curved and relatively thick with a slightly hook cell were similar with the information described by Leslie and Summerell (2006). The hypha of the Fusarium spp. was hyaline, septate, smooth and branched. The microconidia were oval or falcate and macroconidia were fusiform or falcate ('canoe-shaped') having 3-5 septation with large in numbers (Table.4). The morphological variations were clearly recorded that Fusarium solani macroconidia was fusiform with moderately curved. In case of $F$. chlamydosporum was shown that slightly curved with fusiform macroconidia which is varied from $F$. incarnatum and shown fusiform to falcate. The macroconida of $F$. equiseti was shown fusiform to falcate. The different species of Fusarium were recorded in bottle gourd crop and the species like $F$. equiseti, $F$. moniliforme and $F$. solani which is responsible for wilt disease (Shah et al., 2014). The F. equiseti and F. oxysporum are the causal agents which is mainly responsible for causing fusarium wilt in bitter gourd reported by Chowdhury et al., (2019).

\section{Molecular identification of the isolated fungi}

To identify the Fusarium species associated with bitter gourd wilt disease, the ITS 1 and 4 region PCR based amplification and sequencing was carried out for the amplicon of $\sim 560 \mathrm{bp}$. The results were coincided with work of Chowdhury et al., (2019) who has been confirmed Fusarium spp. infecting bitter gourd in Bangladesh. On $1 \%$ agarose gel electrophoresis, the genomic DNA isolated from the fungal isolates showed higher molecular weight and bright band, $1 \mathrm{~kb}$ DNA ladder was used as a marker. 
Table.1 RAPD primers used for genetic variability analysis

\begin{tabular}{|c|c|c|}
\hline S.No & CODE & PRIMER \\
\hline $\mathbf{1 .}$ & M1 & OPF 01 - 5'CCCAAGGTCC 3' \\
\hline $\mathbf{2 .}$ & M2 & OPE 02 - 5' GGTGCGGGAA 3' \\
\hline $\mathbf{3 .}$ & M3 & OPE 03 - 5' CCAGATGCAC 3' \\
\hline $\mathbf{4 .}$ & M4 & OPA 04-5' AATCGGGCTG 3' \\
\hline $\mathbf{5 .}$ & M5 & OPA 05 - 5'AGTCAGCCAC 3' \\
\hline $\mathbf{6 .}$ & M6 & OPF 06 - 5' GGGAATTCGG 3' \\
\hline $\mathbf{7 .}$ & M7 & OPA 07-5' GAAACGGGTG 3' \\
\hline $\mathbf{8 .}$ & M8 & OPF 08 - 5' GGGATATCGG 3' \\
\hline $\mathbf{9 .}$ & M9 & OPA 09 - 5' GGGTAACGC 3' \\
\hline $\mathbf{1 0}$ & M10 & OPA 11 - 5' CAATCGCCGTS 3' \\
\hline
\end{tabular}

Table.2 Survey of Fusarium wilt in bittergourd in Coimbatore, Erode and Dharmapuri districts for assessing disease incidence

\begin{tabular}{|c|c|c|c|c|c|c|c|}
\hline S.NO & LOCATION/DIST & $\begin{array}{c}\text { LATITUDE/ } \\
\text { LONGITUD } \\
\text { E }\end{array}$ & $\begin{array}{l}\text { SOIL } \\
\text { TYPE }\end{array}$ & STAGE & CODE & VARIETY & $\begin{array}{c}\text { DISEASES } \\
\text { INCIDENCE } \\
(\%)\end{array}$ \\
\hline 1. & $\begin{array}{l}\text { Vettaikaranputhur } \\
\text { (Pollachi) }\end{array}$ & $\begin{array}{c}10.5534^{\circ} \mathrm{N} / \\
76.8889^{\circ} \mathrm{E}\end{array}$ & $\begin{array}{c}\text { Red } \\
\text { calcareous }\end{array}$ & Vegetative & VP & Palee & $\begin{array}{c}32.8^{\mathrm{e}} \\
(35.59)\end{array}$ \\
\hline 2. & Papampatti (CBE) & $\begin{array}{c}10.9434^{\circ} \mathrm{N} / \\
77.1126^{\circ} \mathrm{E}\end{array}$ & $\begin{array}{c}\text { Red } \\
\text { calcareous }\end{array}$ & $\begin{array}{c}\text { Harvesting } \\
\text { (II }{ }^{\text {nd }} \text { Picking) }\end{array}$ & PA & Palee & $\begin{array}{c}55.4^{\mathrm{b}} \\
(46.01)\end{array}$ \\
\hline 3. & $\begin{array}{l}\text { Theetharahalli } \\
\text { (Dharmapuri) }\end{array}$ & $\begin{array}{l}12.3251^{\circ} \mathrm{N} / \\
78.0469^{\circ} \mathrm{E}\end{array}$ & $\begin{array}{c}\text { Black } \\
\text { calcareous }\end{array}$ & $\begin{array}{l}\text { Harvesting } \\
\text { (It Picking) }\end{array}$ & DPI & Palee & $\begin{array}{c}45.5^{\mathrm{d}} \\
(41.53)\end{array}$ \\
\hline 4. & $\begin{array}{c}\text { Thelungupalayam } \\
\text { (CBE) }\end{array}$ & $\begin{array}{c}10.9945^{\circ} \mathrm{N} / \\
76.9248^{\circ} \mathrm{E}\end{array}$ & Black soil & $\begin{array}{l}\text { Harvesting } \\
\text { (II }{ }^{\text {st }} \text { Picking) }\end{array}$ & $\mathrm{TP}$ & Palee & $\begin{array}{c}51.7^{\mathrm{c}} \\
(44.33)\end{array}$ \\
\hline 5. & $\begin{array}{l}\text { Madhampatti } \\
\text { (CBE) }\end{array}$ & $\begin{array}{c}10.9728^{\circ} \mathrm{N} / \\
76.8576^{\circ} \mathrm{E}\end{array}$ & Red loamy & $\begin{array}{l}\text { Harvesting } \\
\text { (III }^{\text {rd }} \\
\text { Picking) }\end{array}$ & MA & Palee & $\begin{array}{c}59.3^{\mathrm{a}} \\
(47.78)\end{array}$ \\
\hline 6. & $\begin{array}{l}\text { Vadugapatti } \\
\text { (Erode) }\end{array}$ & $\begin{array}{l}11.1281^{\circ} \mathrm{N} / \\
77.7406^{\circ} \mathrm{E}\end{array}$ & $\begin{array}{c}\text { Deep } \\
\text { loamy soil }\end{array}$ & $\begin{array}{l}\text { Harvesting } \\
\text { (It Picking) }\end{array}$ & VPT & Palee & $\begin{array}{c}26.3^{\mathrm{f}} \\
(32.51)\end{array}$ \\
\hline 7. & Archalur (Erode) & $\begin{array}{l}11.1176^{\circ} \mathrm{N} / \\
77.6881^{\circ} \mathrm{E}\end{array}$ & Red loamy & $\begin{array}{l}\text { Harvesting } \\
\text { (It Picking) }\end{array}$ & AR & Palee & $\begin{array}{c}24.5^{\mathrm{g}} \\
(31.34)\end{array}$ \\
\hline 8. & $\begin{array}{l}\text { Elumathur } \\
\text { (Erode) }\end{array}$ & $\begin{array}{l}11.1868^{\circ} \mathrm{N} / \\
77.7738^{\circ} \mathrm{E}\end{array}$ & $\begin{array}{c}\text { Deep } \\
\text { loamy soil }\end{array}$ & $\begin{array}{l}\text { Harvesting } \\
\text { (II }{ }^{\text {nd }} \text { Picking) }\end{array}$ & EL & Palee & $\begin{array}{c}31.8^{\mathrm{e}} \\
(35.10)\end{array}$ \\
\hline 9. & $\begin{array}{l}\text { Injampalayam } \\
\text { (Erode) }\end{array}$ & $\begin{array}{l}11.2043^{\circ} \mathrm{N} / \\
77.8196^{\circ} \mathrm{E}\end{array}$ & $\begin{array}{c}\text { Black } \\
\text { calcareous }\end{array}$ & $\begin{array}{l}\text { Harvesting } \\
\text { (Ist Picking) }\end{array}$ & IJ & Palee & $\begin{array}{c}20.3^{\mathrm{h}} \\
(28.97)\end{array}$ \\
\hline 10. & TNAU (CBE) & $\begin{array}{l}11.0123^{\circ} \mathrm{N} / \\
76.9355^{\circ} \mathrm{E}\end{array}$ & Loamy & vegetative & $\mathrm{TN}$ & Co 1 & $\begin{array}{c}15.6^{\mathrm{i}} \\
(26.05)\end{array}$ \\
\hline
\end{tabular}

*Values are mean of three replicates

Values in parentheses are arcsine transformed values

In a column, means followed by a common letter are not significantly different at the 5\% level by DMRT 
Table.3 In vitro pathogenicity assay of Fusarium spp. in bittergourd

\begin{tabular}{|c|c|c|c|}
\hline S.NO & $\begin{array}{c}\text { ISOLATE } \\
\text { CODE }\end{array}$ & WILTING (DAI) \\
\hline $\mathbf{1 .}$ & VP & Fusarium solani & $13^{\text {a }}$ \\
\hline $\mathbf{2 .}$ & PA & Fusarium equiseti & $23^{\text {cd }}$ \\
\hline $\mathbf{3 .}$ & DPI & Fusarium falciforme & $26^{\text {def }}$ \\
\hline $\mathbf{4 .}$ & TP & Fusarium solani & $18^{\text {b }}$ \\
\hline $\mathbf{5 .}$ & MA & Fusarium incarnatum & $29^{\text {f }}$ \\
\hline $\mathbf{6 .}$ & VPT & Fusarium solani & $22^{\text {c }}$ \\
\hline $\mathbf{7 .}$ & AR & Fusarium chlamydosporum & $28^{\text {ef }}$ \\
\hline $\mathbf{8 .}$ & EL & Fusarium solani & $15^{\text {ab }}$ \\
\hline $\mathbf{9 .}$ & IJ & Fusarium falciforme & $25^{\text {cde }}$ \\
\hline $\mathbf{1 0}$ & TN & Fusarium chlamydosporum & $24^{\text {cd }}$ \\
\hline
\end{tabular}

*Values are mean of three replicates

In a column, means followed by a common letter are not significantly different at the 5\% level by DMRT

Table.4 Morphometric analysis of Fusarium spp. under light microscope at 40xmagnification

\begin{tabular}{|c|c|c|c|c|c|c|c|}
\hline \multirow[t]{3}{*}{ S.NO } & \multirow{3}{*}{$\begin{array}{l}\text { ISOLATES } \\
\text { CODE }\end{array}$} & \multirow[t]{3}{*}{ ISOLATES } & \multicolumn{5}{|c|}{ MORPHOLOGICAL CHARACTERS } \\
\hline & & & \multicolumn{2}{|c|}{ MICROCONIDA } & \multicolumn{2}{|c|}{ MACROCONIDIA } & \multirow[t]{2}{*}{ CHLAMYDOSPORE } \\
\hline & & & SHAPE & $\begin{array}{c}\text { SIZE } \\
(\mu \mathrm{m})\end{array}$ & SHAPE & $\begin{array}{c}\text { SIZE } \\
(\mu \mathrm{m})\end{array}$ & \\
\hline 1. & VP & Fusarium solani & Oval & $\begin{array}{c}8-16 \times 3- \\
5\end{array}$ & $\begin{array}{c}\text { Fusiform, often } \\
\text { moderately } \\
\text { curved }\end{array}$ & $\begin{array}{c}28- \\
42 \times 4-6\end{array}$ & Terminal and intercalary \\
\hline 2. & PA & $\begin{array}{l}\text { Fusarium } \\
\text { equiseti }\end{array}$ & $\begin{array}{l}\text { Oval and } \\
\text { elongated }\end{array}$ & $\begin{array}{c}8-16 \\
\times 2.5-5\end{array}$ & $\begin{array}{l}\text { Fusiform to } \\
\text { falcate }\end{array}$ & $\begin{array}{c}20-32 \times \\
4-5\end{array}$ & Terminal and intercalary \\
\hline 3. & DPI & $\begin{array}{l}\text { Fusarium } \\
\text { falciforme }\end{array}$ & Oval & $\begin{array}{c}11-13 \times \\
4-4.6\end{array}$ & Falcate & $\begin{array}{c}22-26.5 \\
\times 5-6\end{array}$ & Terminal and intercalary \\
\hline 4. & $\mathrm{TP}$ & Fusarium solani & Oval & $\begin{array}{c}7-15 \times 4.5 \\
-5\end{array}$ & $\begin{array}{c}\text { Fusiform, often } \\
\text { moderately } \\
\text { curved }\end{array}$ & $\begin{array}{c}30-41 \times \\
4-5.5\end{array}$ & Terminal and intercalary \\
\hline 5. & MA & $\begin{array}{l}\text { Fusarium } \\
\text { incarnatum }\end{array}$ & $\begin{array}{l}\text { Oval and } \\
\text { elongated }\end{array}$ & $\begin{array}{r}9-10.5 \\
\times 3-4.2\end{array}$ & $\begin{array}{l}\text { Fusiform to } \\
\text { falcate }\end{array}$ & $\begin{array}{c}28-33.5 \\
\times 4-4.7\end{array}$ & Not found \\
\hline 6. & VPT & Fusarium solani & Oval & $\begin{array}{c}8-16 \times 3- \\
5\end{array}$ & $\begin{array}{c}\text { Fusiform, often } \\
\text { moderately } \\
\text { curved }\end{array}$ & $\begin{array}{c}30-41 \times \\
4-6\end{array}$ & Terminal and intercalary \\
\hline 7. & AR & $\begin{array}{c}\text { Fusarium } \\
\text { chlamydosporu } \\
m\end{array}$ & $\begin{array}{c}\text { Oval to } \\
\text { elongated }\end{array}$ & $\begin{array}{c}6-26 \times 2- \\
4\end{array}$ & $\begin{array}{c}\text { Fusiform, } \\
\text { slightly curved }\end{array}$ & $\begin{array}{r}30-38 \\
\times 3-4.5\end{array}$ & Terminal and intercalary \\
\hline 8. & EL & Fusarium solani & Oval & $\begin{array}{l}7.5-15 \times \\
3.5-5\end{array}$ & $\begin{array}{c}\text { Fusiform, often } \\
\text { moderately } \\
\text { curved }\end{array}$ & $\begin{array}{l}29-40 \\
\times 4-6\end{array}$ & Terminal and intercalary \\
\hline 9. & IJ & $\begin{array}{l}\text { Fusarium } \\
\text { falciforme }\end{array}$ & Oval & $\begin{array}{c}12-13.5 \times \\
3-4.6\end{array}$ & Falcate & $\begin{array}{c}22.2- \\
26.3 \times \\
5.4-6.1\end{array}$ & Terminal and intercalary \\
\hline 10. & $\mathrm{TN}$ & $\begin{array}{c}\text { Fusarium } \\
\text { chlamydosporu } \\
m\end{array}$ & $\begin{array}{c}\text { Oval to } \\
\text { elongated }\end{array}$ & $\begin{array}{c}7-25.5 \times \\
3-4\end{array}$ & $\begin{array}{c}\text { Fusiform, } \\
\text { slightly curved }\end{array}$ & $\begin{array}{r}31-36.5 \\
\times 3-4.4\end{array}$ & Terminal and intercalary \\
\hline
\end{tabular}


Table.5 The sequencing results of 10 isolates of pathogen

\begin{tabular}{|c|c|c|c|}
\hline S.No & Code & Pathogen & Accession no \\
\hline $\mathbf{1 .}$ & VP & Fusarium solani & MN999964 \\
\hline $\mathbf{2 .}$ & PA & Fusarium equiseti & MN999973 \\
\hline $\mathbf{3 .}$ & DPI & Fusarium falciforme & MN999971 \\
\hline $\mathbf{4 .}$ & TP & Fusarium solani & MN999965 \\
\hline $\mathbf{5 .}$ & MA & Fusarium incarnatum & MN999974 \\
\hline $\mathbf{6 .}$ & VPT & Fusarium solani & MN999966 \\
\hline $\mathbf{7 .}$ & AR & Fusarium chlamydosporum & MN999969 \\
\hline $\mathbf{8 .}$ & EL & Fusarium solani & MN999967 \\
\hline $\mathbf{9 .}$ & IJ & Fusarium falciforme & MN999972 \\
\hline $\mathbf{1 0 .}$ & TN & Fusarium chlamydosporum & MN999970 \\
\hline
\end{tabular}
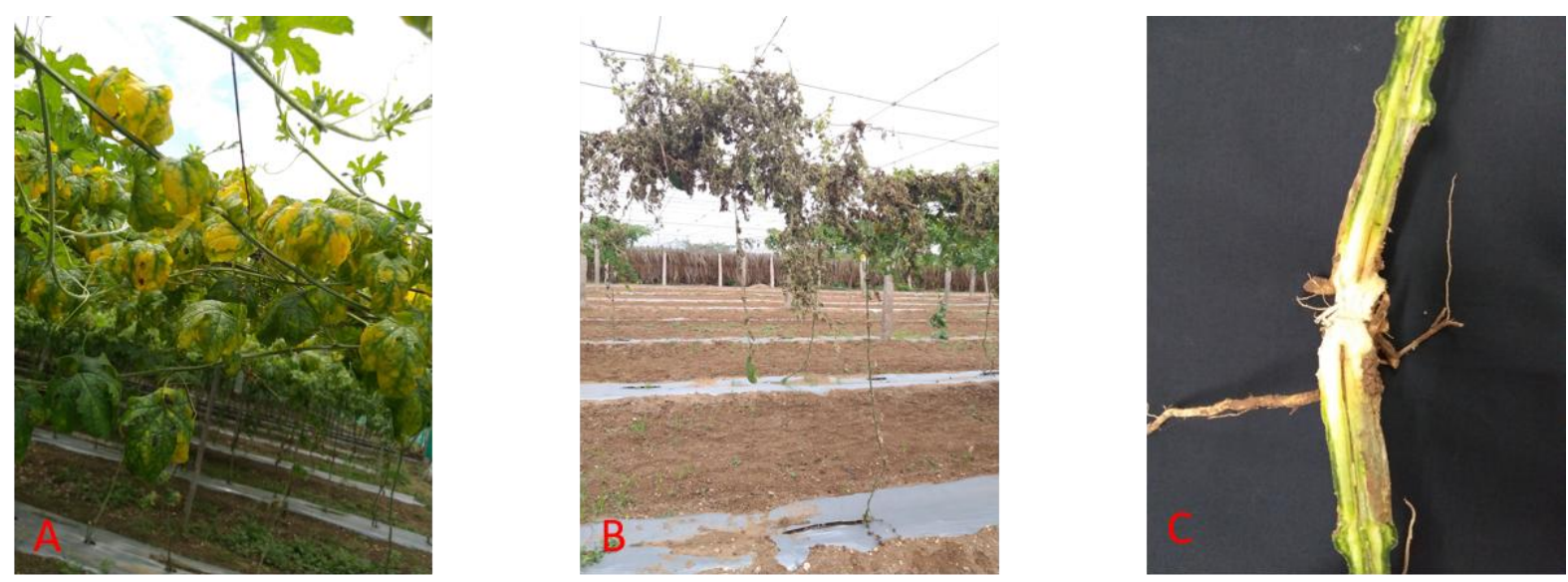

A) Yellowing of crown leaves B) Complete wilting and death

C) Dark brown vascular discoloration

Fig.1 Survey and collection of wilt infected plant samples from farmer's field
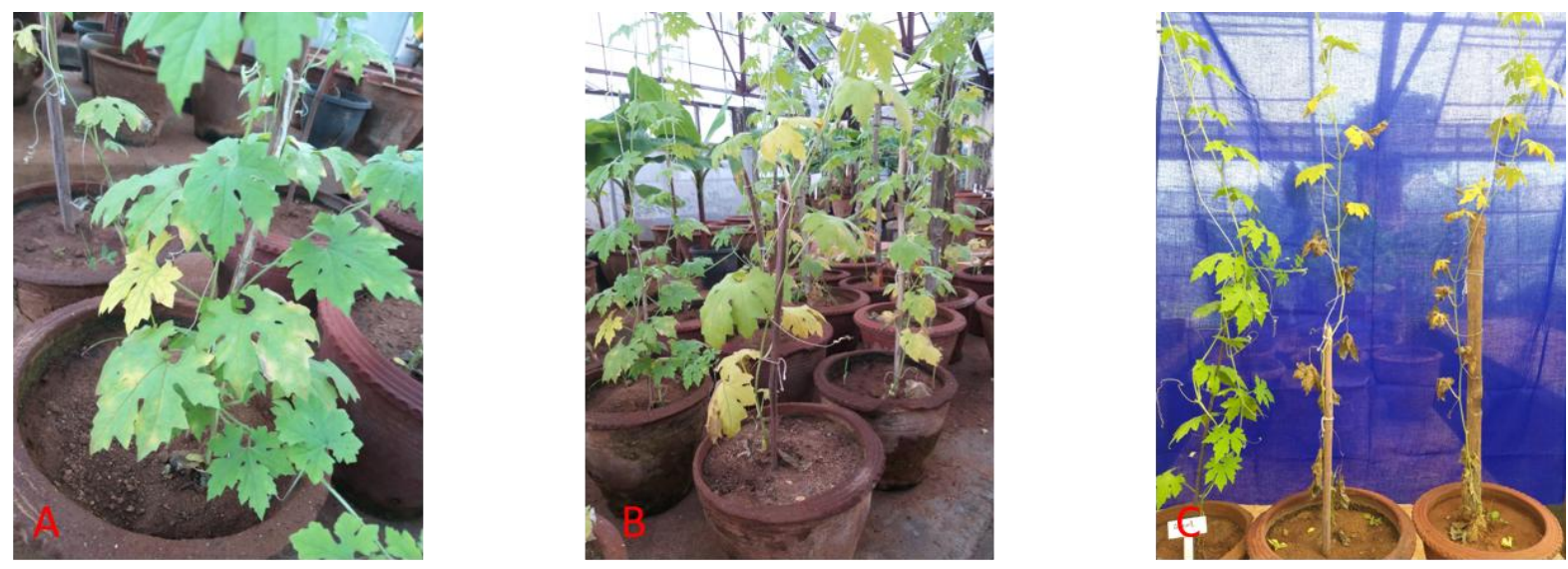

Yellowing of leaves B) Wilting of leaves C) Drying and wilting of leaves compared to control

Fig.2 Pathogenicity assay under glass house condition 


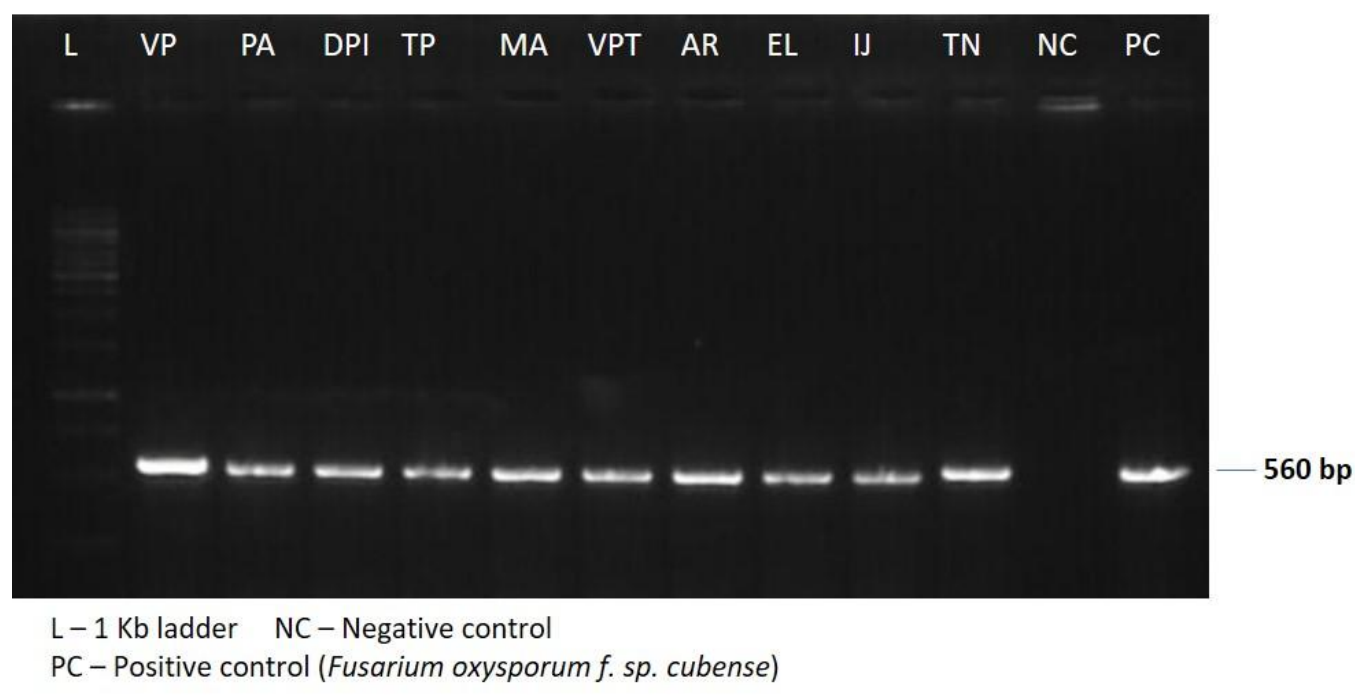

Fig.3 PCR amplification and gel electrophoresis of ITS region of Fusarium spp. infecting bitter gourd
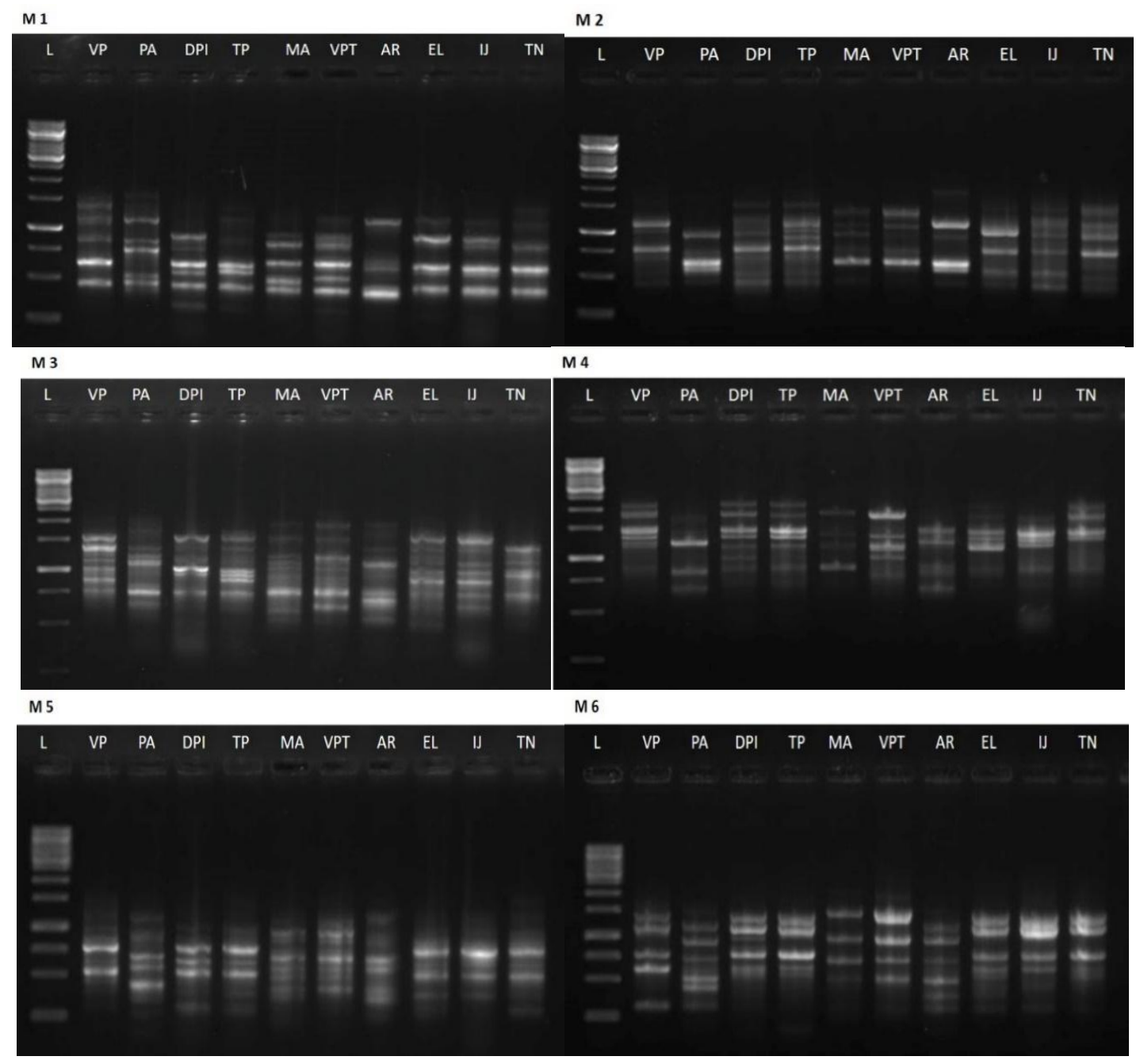


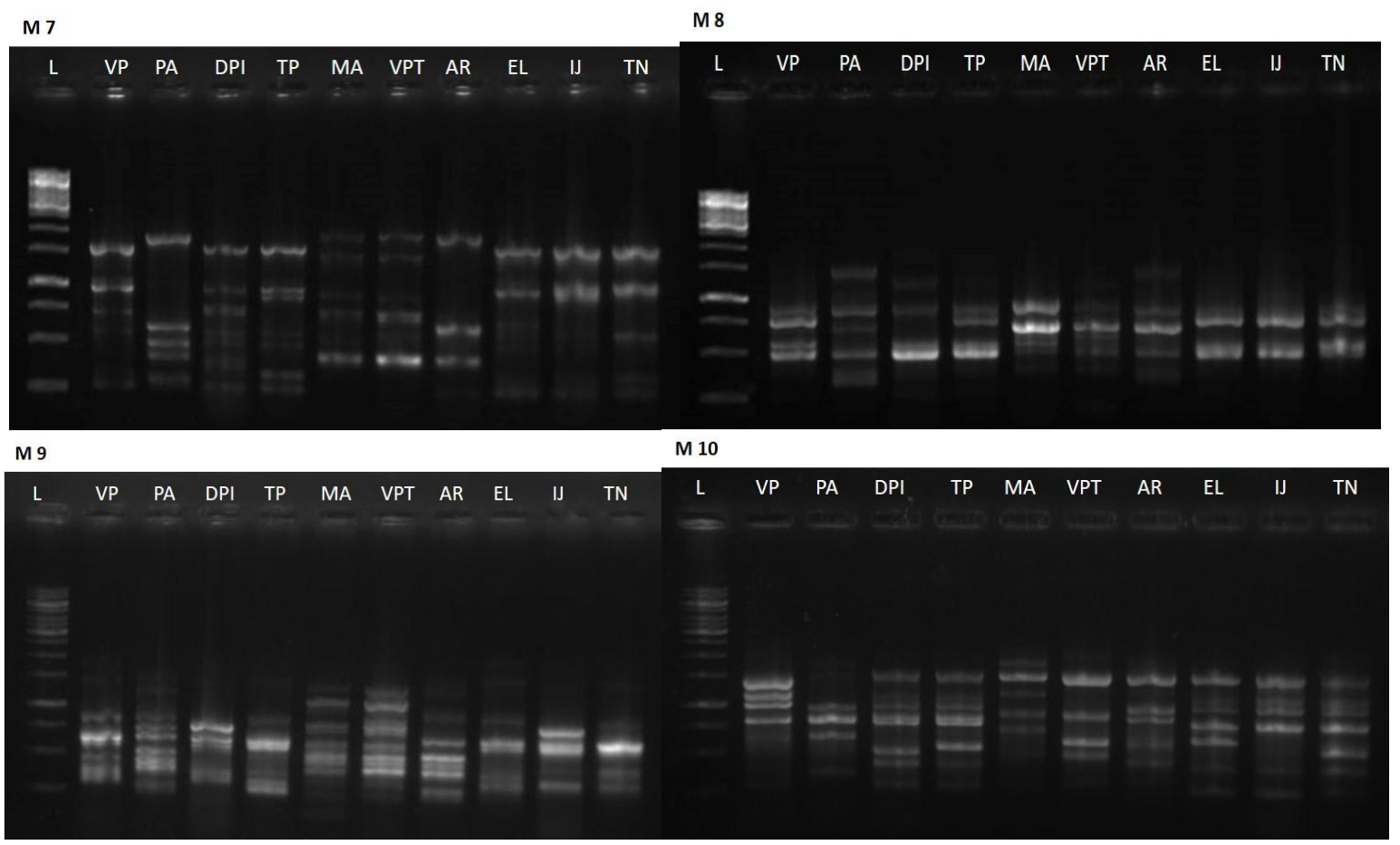

Fig.4 RAPD marker analysis of genetic variability of Fusarium spp. infecting bitter gourd

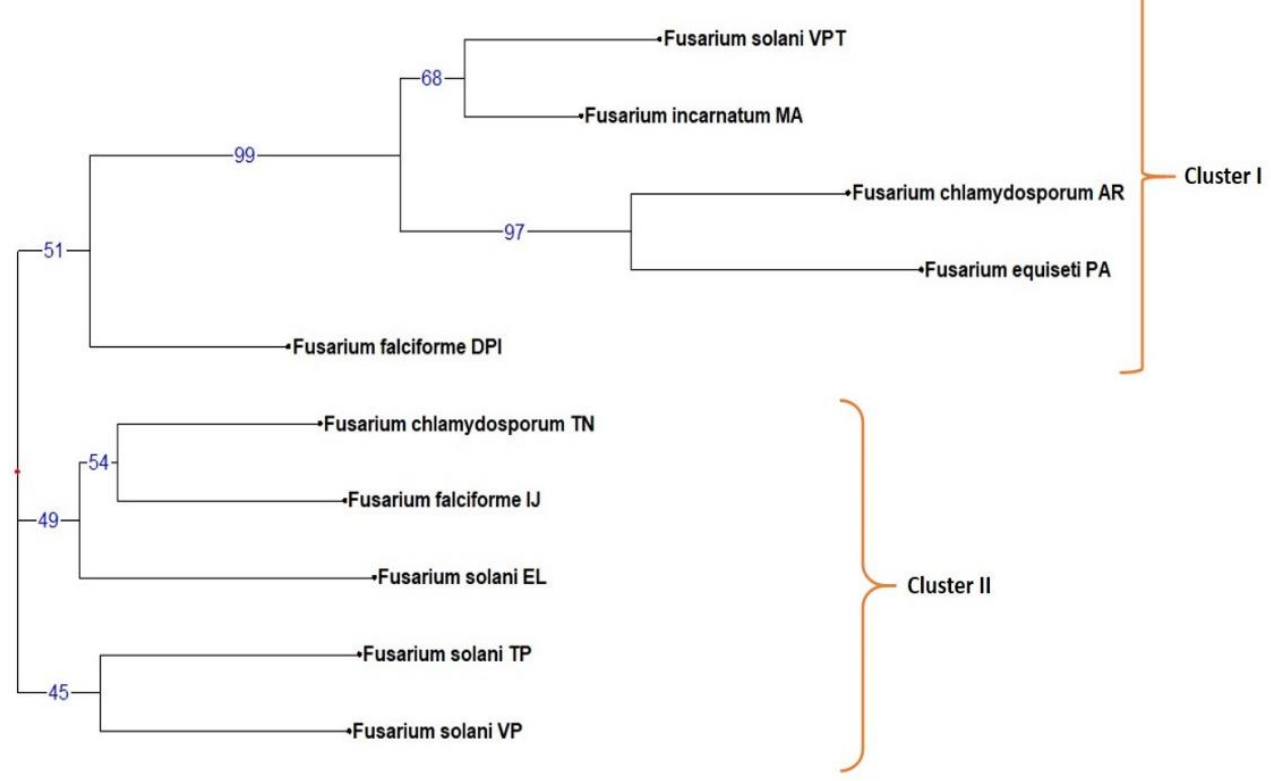

Fig.5 Phylogenetic tree analysis by RAPD marker

The universal primers, ITS-1 5, band of around 560bp (Fig.3). The result was TCCGTAGCTGAACCTGCCG 3' and ITS-4 5' TCCTCCGCTTATTGATATGC 3', were used to amplify a region of fungal genome named the $18 \mathrm{~S}$ of ribosomal DNA gene of different Fusarium spp. isolates. The PCR amplified fragments of the isolates yielded coincided with the findings of Sreegayathri et al., (2018) who has been confirmed the F. Solani amplified at $\sim 560 \mathrm{bp}$. The sequenced results of the different isolates were shown more than $97 \%$ similarity with respective species of the Fusarium. The sequenced result 
and accession number for individual isolates were given in Table.5.

\section{Molecular variability of fusarium spp.}

Gupta et al., (2012) utilized RAPD analysis in order to study the genetic diversity and fingerprinting of fusarium spp. infecting guava. The results revealed that Fusarium oxysporumf.sp. psidii divided into three clusters, were as Fusarium solani were formed two clusters based on number banding pattern. The genetic variations among the Fusarium spp. were observed which indicates RAPD is a potential marker for genetic characterization (Fig.4).

The result of RAPD analysis revealed that there are two major clusters were formed (Fig.5). In custer1, two sub clusters were formed. In sub cluster IFusarium solani VPT, Fusarium incarnatum MA occupied a separate branch. In sub cluster II, Fusarium chlamydosporum AR, Fusarium equiseti PA occupied separate branch. The Fusarium falciforme DPI occupied separate clusters that are well separated from another Fusarium spp. in major cluster I.

In major cluster II, there are two subclusters were formed, which showed more virulence in pathogenicity assay. The Fusarium chlamydosporum TN, Fusarium falciforme IJ and Fusarium solani EL grouped under subcluster. In sub cluster II Fusariumsolani TP, Fusarium solani VP were clustered together. The results revealed that variability in the Fusarium spp. according geographical location at molecular level. The variability of pathogen reflected between and within the species.

\section{Acknowledgments}

The authors are thankful to the Director, CPPS, Head of the Department and Professor of Department of Plant Pathology, TNAU, Coimbatore for providing support, guidance and financial assistance. The authors would like to acknowledge DST-FIST and UGCSAP-DRSI for providing facilities at Department of Plant Pathology.

\section{References}

Ashwathi, S., Ushamalini, C., Parthasarathy, S. and Nakkeeran, S., 2017. Morphological and molecular characterization of Fusarium spp. associated with Vascular Wilt of Coriander in India. Journal of Pharmacognosy and Phytochemistry, 6(5), pp.1055-1059.

Behera TK (2004) Heterosis in bitter gourd. J New Seeds. 6(2/3):217-222.

Bentley, S., Pegg, K.G. and Dale, J.L., 1995. Genetic variation among a world-wide collection of isolates of Fusarium oxysporum $f$. sp. cubense analysed by RAPD-PCR fingerprinting. Mycological Research, 99(11), pp.1378-1384.

Chowdhury, M.K., Jahan, M.S., Akhtar, S., Islam, M.A., Islam, M.A., Sikdar, B. and Hasan, M.F., 2019. Characterization of fungal pathogens causing diseases in bitter gourd and establishment of their eco-friendly control measure. Int J Multi Res and Develop, 6(1), pp.109-115.

Gupta, V.K., 2012. PCR-RAPD profiling of Fusarium spp. causing guava wilt disease in India. Journal of Environmental Science and Health, Part B, 47(4), pp.315-325.

http://www.indiastat.com/table/agriculturedata/2/horticultur/118/962234/data.aspx referenced by 22.02.2020

Karthick, M., Kamalakannan, A., Malathi, V.G., Paranidharan, V., Sivakumar, U. and Kavino Mand Gowrisri, N., 2019. Morphological characterization of Plasmopara viticola, the inciting agent 
of grapes downy mildew. Journal of Pharmacognosy and Phytochemistry, 8(6), pp.209-212.

Karthick, M., Kamalakannan, A., Malathi, V.G., Paranidharan, V., Sivakumar, U., Kavino, M. and Gowrisri, N., 2019. Phenotypic Characterization and Molecular Phylogenetic Relationship of Erysiphe necator Infecting Grapes (Vitis vinifera). Current Journal of Applied Science and Technology, pp.1-10.

Leslie, J.F. and Summerell, B.A., 2006. Fusarium laboratory workshops--A recent history. Mycotoxin Research, 22(2), p.73.

Muhammad A, Hussain S, Muhammad R, Khan F. Evaluvation of Various Biocontrol Agents (Plant Extracts) on Linear Colony Growth of the Fungus Fusarium Oxysporum Causing Onion Wilt. Int $\mathbf{J}$ Environ \& Agri Sci. 2019;3:023.

Satkar KP, Kulthe AA, Chalke PR (2013) Preparation of bitter gourd ready to serve beverage and effect of storage temperature on its keeping quality. Bioscan. 8 (1): 115-117.

Shah, N. and Jiskani, M.M., 2014. Pathogeniciity Test and Inoculum Level of Fusarium Wilt of Bottle gourd (Lagenariasiceraria). Persian Gulf Crop Protection, 3(3).

Singh, A.K., Pan, R.S. and Bhavana, P., 2013.
Heterosis and combining ability analysis in bittergourd (Momordica charantia L.). The Bioscan, 8(4), pp.1533-1536.

Sreegayathri, E., Karthikeyan, G., Rajendran, L., Shanthi, A. and Jegathesh, R.R., Effect of Root Knot Nematode (Meloidogyne incognita) Infestation on Severity of Wilt (Fusarium solani) in Bitter Gourd and its Management.

Tamilselvi, N.A., Pugalendhi, L. and Raguchander, T., 2016. Exploiting cucurbitaceous species as rootstocks for management of'Fusariumwilt ('Fusarium oxysporum') in bitter gourd. Australian Journal of Crop Science, 10(10), p.1460.

Tamilselvi NA (2014) Grafting studies in bitter gourd. Ph.D (Hort.) Thesis, Tamil Nadu Agricultural University, Coimbatore.

Tamilselvi NA, Pugalendhi L (2015) Agronomic evaluation of bitter gourd grafts for yield and quality. Bioscan. 10 (3) 1331-1334.

White, T.M., Bruns, T., Lee, S., Taylor, J., 1990. Amplification and direct sequencing of fungal ribosomal RNA for phylogenetics. In: Innis, M.A., Gelfand, D.H., Sninsky, J.J., White, T.J. (Eds.), PCR protocols: a guide to methods and applications. Academic Press, San Diego, CA, pp. 315-321.

\section{How to cite this article:}

Saran Kumar. M., S. K. Manoranjitham, V. Sendhilvel and Rajasree. V. 2020. Morphological Characterization and Genetic Diversity of Fusarium spp. Infecting Bitter Gourd. Int.J.Curr.Microbiol.App.Sci. 9(05): 818-828. doi: https://doi.org/10.20546/ijcmas.2020.905.091 